\title{
Okul Dışı Öğrenme (ODÖ) Faaliyetlerine Yönelik Öğretmen Öz-Yeterlik İnançları Ölçeğinin Geliştirilmesi
}

Development of a Scale to Measure Teachers' Self-Efficacy Beliefs Toward Out-of-School Learning (OoSL) Activities

Cennet Göloğlu Demir, Filiz Çetin

Yazar Bilgileri

Cennet Göloğlu Demir Dr. Öğr. Üyesi, Bandırma Onyedi Eylül Üniversitesi, Çocuk Gelişimi, gologlu.cennet@gmail.com

\section{Filiz Çetin}

Doç. Dr., Gazi Üniversitesi, Gazi Eğitim Fakültesi, Eğitim Bilimleri,

ficetin@gazi.edu.tr

\section{ÖZ}

Bu araştırmanın amacı “Okul Dışı Öğrenme (ODÖ) Faaliyetlerine Yönelik Öğretmen Özyeterlik İnançları Ölçeği“" geliştirmektir. Araştırma 332 öğretmenden oluşan çalışma grubu üzerinde yürütülmüştür. Ölçeğin kapsam ve görünüş geçerliği için uzman görüşüne başvurulmuş, yapı geçerliği için Açımlayıcı Faktör Analizi (AFA) ve Doğrulayıcı Faktör Analizi (DFA) uygulanmıştır. AFA sonucunda toplam varyansın \%61,01'ini açılayan, 29 madde ve dört faktörden oluşan bir yapı elde edilmiştir. Ortaya çıan faktörler; "Hazırlık Yeterliliği", "Uygulama ve Değerlendirme Yeterliliği", "Öğrenmeyi Destekleme Yeterliliği" ve "Bilgi ve Deneyim Yeterliliği" olarak adlandırılmıştır. DFA sonuçları ölçeğin "kabul edilebilir uyum" ve "mükemmel uyum" indekslerine sahip olduğunu göstermiştir. Ölçümlerin güvenirliği Cronbach Alpha ve bileşik güvenirlik yöntemleriyle incelenmiş ve hesaplanan güvenirlik katsayılarının kabul edilebilir sınırlar içerisinde yer aldığı saptanmıştır. Tukey Non-Additivity test sonuçları ölçeğin toplanabilir özellikte olduğunu göstermektedir. Madde toplam korelasyonu ile \%27'lik alt-üst grup karşılaştırmaları ölçekte yer alan maddelerin tamamının ayırt edici olduğunu göstermiştir. Sonuç olarak öğretmenlerin ODÖ faaliyetlerine yönelik öz-yeterlik inançlarını ortaya koyacak geçerli ve güvenilir ölçümler veren bir ölçme aracı elde edilmiştir.

\begin{tabular}{|c|c|}
\hline Makale Bilgileri & ABSTRACT \\
\hline Anahtar Kelimeler & The present study aimed to develop a scale to measure teachers' self-efficacy beliefs toward \\
\hline Okul Dışı Öğrenme & out-of-school learning (OoSL) activities. The study was conducted with 332 teachers. Expert \\
\hline Öz-Yeterlik & opinion was sought on the content validity and face validity of the scale. An Exploratory \\
\hline İnformal Öğrenme & Factor Analysis (EFA) and a Confirmatory Factor Analysis (CFA) were performed for the \\
\hline Non-formal Öğrenme & construct validity of the scale. The EFA yielded a structure consisting of 29 items and four \\
\hline Ölçek Geliştirme & factors, which accounted for $61.01 \%$ of the variance. The factors that were revealed were \\
\hline & labeled as follows: "planning self-efficacy", "implementation and assessment self-efficacy", \\
\hline Keywords & "self-efficacy to support learning", and "knowledge and experience self-efficacy". The results \\
\hline Out-of-school Learning & of the CFA demonstrated that the scale had indices indicating an "acceptable fit" or a \\
\hline Self-Efficacy & "perfect fit". The reliability of the measurements was examined utilizing Cronbach Alpha \\
\hline Informal Learning & and composite reliability methods, and it was determined that the calculated reliability \\
\hline Non-Formal Learning & coefficients were within acceptable limits. The results of Tukey's Test for Non-Additivity \\
\hline Scale Development & $\begin{array}{l}\text { indicated that the scale was additive. The item-total correlation and the } 27 \% \text { bottom-top } \\
\text { group comparisons showed that all of the items on the scale were discriminatory. }\end{array}$ \\
\hline Makale Geçmişi & Ultimately, a scale to reveal teachers' self-efficacy beliefs toward OoSL activities and that \\
\hline Geliş: 22.03.2021 & gives valid and reliable measurements was obtained. \\
\hline
\end{tabular}

Düzeltme: 07.04.2021

Kabul: 15.04 .2021 


\section{Giriş}

Yirmi birinci yüzyılda öğretmenlerden, konu ve öğrenci ihtiyaçlarını dikkate alarak çeşitli öğretim yöntem ve teknikleri ile öğrenme ve öğretme süreçlerini zenginleştirmesi beklenmektedir. Bu durum sadece yöntem ve teknik seçimiyle sınırlı kalmayıp farklı öğrenme ortamlarında öğretmenlerin öğretim faaliyetlerini gerçekleştirmelerini de ön plana çıkarmaktadır. Öğrenenler açısından ele alındığında öğrenme yalnızca okullarda sınıf ortamında gerçekleşmez, öğrenenler sınıf ortamının dışında da öğrenmeyi tecrübe ederler (Şen, Ertaş-Kılıç, Oktay, Ekinci ve Kadırhan, 2021). Bu durum okul dışı öğrenme (ODÖ) ortamları kavramı olarak literatürde yer almaktadır (Falk ve Dierking, 2000; Tal, 2012). Burada dikkat edilmesi gereken husus ODÖ ortamının açık alan (Outdoor) ile sınırlandırılmamasıdır. ODÖ ortamları, geleneksel öğrenme ortamlarında bulunmayan farklı öğrenme olanakları sunan (Ertaş-Kılıç ve Şen, 2014) informal ve non-formal öğrenme ortamlarını kapsamaktadır. Non-formal öğrenme ortamları; yapılandırılmış ve önceden planlanmış öğrenmeyi destekleyen, öğretmen liderliğinde, öğrenmenin genellikle değerlendirilmediği, bilginin yapılandırılması ve geliştirilmesine olanak sağlayan öğrenme ortamlarıdır. İnformal öğrenme ortamları ise amaçlı ve planlı olmayan, öğrenmenin değerlendirilmediği ve öğrenenin kendi liderliğinde öğrenmenin gerçekleştiği ortamlardır (Eshach, 2007). ODÖ faaliyetleri ise, non-formal ve informal öğrenme ortamlarının formal öğrenme için kullanılmasını sağlamaktadır (Salmi, 1993). Bu çalışmada ODÖ faaliyetleri, öğretim programının amaçlarına bağlı olarak, okul dışındaki alanlar (tabiat parkları, müze, bilim fuarları, fabrika vb.) ve kurumlarda (üniversite, sanayi odaları vd.), rehber ya da öğretmen eşliğinde önceden planlanmış, yapılandırılmış ve öğrenmenin değerlendirildiği faaliyetler olarak ele alınmıştır.

Son yıllarda yapılan ODÖ faaliyetleri konusundaki araştırmalar, ODÖ faaliyetlerinin akademik başarı ve tutum üzerinde olumlu etkileri olduğunu (Andersson ve Johansson, 2013; Nadelson ve Jordan, 2012; Sturm ve Bogner, 2010; Şentürk ve Özdemir, 2014; Yavuz, 2012), öğrenci ilgisini arttırarak motivasyon sağladığını (Fägerstam ve Blom, 2013), gözlem becerisi ile kalıcı bilgi edinmeyi sağladığını (Balkan-Kıyıcı ve Atabek-Yiğit, 2010; Parvin ve Stephenson, 2004), günlük hayatla ilişki kurmayı kolaylaştırdığını (Ertaş, Şen ve Parmaksızoğlu, 2011; Tortop ve Özek, 2013) ve öğrencinin bilişsel ve duyuşsal yönden gelişmesini sağladığını (Berberoğlu ve Uygun, 2013; Güler, 2011) ortaya koymaktadır. Öğrenenler üzerinde olumlu etkileri olduğu ortaya konulan ODÖ faaliyetleri, dikkatlice tasarlanıp uygulandığında öğretim programının amaçlarına önemli ölçüde hizmet etmektedir (Andrew, Maggie ve Sarah, 2010). Bunun aksine plansız ve iyi organize edilmemiş faaliyetler de öğretim programının amaçlarına ulaşılmasının önünde bir engel olarak görülmektedir (Griffin ve Symington, 1997). İlgili alanyazında öğretmenlerin ODÖ faaliyetleri konusunda yeterli bilgi, beceri ve deneyime sahip olmadıkları (Smith-Sebasto ve Smith, 1997; Thomas, 2010) ve bunlara 
bağlı olarak da öğrencileri kontrol etmekte güçlük yaşadıkları (Thomas, 2010), öğretim programı ile arasında ilişki kuramadıkları ortaya konulmuştur (McComas, 2006). Bu bağlamda ODÖ faaliyetlerinin planlı ve programlı eğitsel amaçlara yönelik öğrenme yaşantılarını içermesi gerekir. Aksi durumda öğretim amacından uzaklaşarak boş zaman faaliyetine veya turistik bir geziye dönüşebilir (Bolat ve Köroğlu, 2020). Şen (2019) ODÖ faaliyetlerinin derslerde kullanılmasında içerik-yöntem ve ortam ilişkisine dikkat çekmektedir. İçerik öğretim programındaki kazanım ve becerileri, yöntem yaratıcı drama, argümantasyon veya istasyon gibi yöntem ve teknikleri, ortam ise içerik ve yöntem için en uygun olan müze, hastane, okul bahçesi vb. ortamdır. Burada uygun ortamda belirlenmiş yöntemle kazanımlara ulaşılmaya çalışması okul dışı öğrenmeyi sadece farklı bir ortamda öğretim süreci gerçekleştirme veya geziden ayıran en önemli unsurdur. Bu faaliyetlerin gerçekleştirilmesi üç aşamada gerçekleşmektedir. Bu aşamalar, faaliyet öncesi hazırlıklar, faaliyetin uygulanması ve faaliyet sonrası değerlendirmedir (Şen, 2019). Bu araştırmada ölçek maddelerinin hazırlanması sürecinde de bu aşama ve ilişkiler dikkate alınmıştır.

Bireylerin düşünceleri, inançları ve hissettikleri, onların davranışları üzerinde etkilidir (Bandura, 1986, s. 25). Öz-yeterlik inançları da bu davranışlarını etkileyen önemli bir unsur olarak görülmektedir. Bandura (1977, 1994, 1997) öz yeterlik algısını, “bireyin belli bir performansı gösterebilmek için eylemleri organize edip uygulayabilmesine yönelik kapasitesi hakkında kişisel yargıları" ve "bireyin belli bir görevi yapma kapasitesine dair inancı" şeklinde tanımlamaktadır. Bir başkada ifadeyle bireyin becerisini kullanarak yapabileceklerine ilişkin kendi kapasitesine yönelik yargıları (Senemoğlu, 2004) olduğu söylenebilir. Hoy ve Spero (2005), öz-yeterliğin gelecek odaklı olduğunu ve yeterliğin seviyesine göre değil yeterlik algısına göre işlediğini belirtmiştir. Bu bağlamda ODÖ faaliyeti konusunda ayn düzeyde pedagojik bilgi ve beceriye sahip olan iki öğretmenden, yeterlik algısı yüksek olanın ODÖ faaliyeti geçekleştirme olasılı̆̆ının daha fazla olacağı söylenebilir. Dolayısıyla öğretmenlerin gelecekteki davranışlarını yordama açısından öz-yeterliklerinin belirlenmesi oldukça önemlidir. Bıkmaz (2004) öğretmenlerin öğretimle ilgili görevlerini yerine getirme konusundaki öz-yeterlik inançlarının, ayrılan zaman ve harcanan çabayla ilişkili olduğunu belirtmektedir. Bu bağlamda öğretmenlerin ODÖ faaliyetlerine yönelik öz-yeterlik inançlarının belirlenmesi öğretmenlerin bu faaliyetlere zaman ayırıp ayırmayacağı ya da faaliyetleri gerçekleştirmek için gereken çabayı gösterip göstermeyeceğinin de bir göstergesi olacaktır.

Bandura, (1997, s. 42-43) öz-yeterlik inançlarının sahip olduğu üç boyuttan bahsetmektedir. Bunlar öz-yeterliğin seviyesi, genellenebilirliği ve gücüdür. Yapılacak bir işin zor veya kolay olması, bireyin bu işe karşı geliştireceği öz-yeterlik inancının seviyesini belirlemede önemlidir. Bireylerin özyeterlik inançlarının ne ölçüde genellenebileceği “yapılan faaliyetlerin benzerliğine, bilişsel, duyuşsal ve davranışsal açıdan yeteneklerinin türüne, niteliksel olarak durumların özelliğine ve davranışı 
yönlendiren kişinin karakterine" bağlıdır. Son olarak bireyin bir işteki başarısız deneyimlerine rağmen o işe devam edip etmemesi ya da güçlükler karşısında ne kadar dayandığı öz-yeterlik inancının gücünü gösterir. ODÖ faaliyetleri çok iyi bir hazırlık ve planlama gerektirmektedir. Alışılagelmiş sınıf ortamının dışına çıkılması, yasal prosedürler gibi süreçlerden dolayı güçlü öz-yeterlik inançlarına sahip olmayı gerekli kılmaktadır. Sonuç öğretmenlerin ODÖ faaliyetlerine yönelik öz-yeterlik inançlarının araştırmacılar tarafından ortaya konulması oldukça önemlidir. Bu da geçerli ve güvenilir ölçümler veren ölçme aracının geliştirilmesini gerekli kılmaktadır.

İlgili alanyazında ODÖ faaliyetlerine yönelik öğretmen algılarını belirlemek üzere geliştirilmiş sınırlı sayıda çalışmaya rastlanılmıştır. Bunlardan ilki, Bozdoğan (2016) tarafından okul dışı çevrelere eğitim amaçlı gezi düzenleyebilme öz-yeterlik inancına yönelik bir ölçek geliştirilme çalışmasıdır. Ölçeğin çalışma grubu 358 öğretmen adayından oluşmaktadır. Geçerlik ve güvenirlik analizleri sonucunda tek faktörlü ve 30 maddeden oluşan bir ölçek elde edilmiştir. Balkan-Kıyıcı ve YavuzTopaloğlu (2016) fen öğretiminde sınıf içi eğitim etkinliklerini destekleyen okul dışı öğrenme ortamlarının kullanımına yönelik öğretmenlerin tutum, davranış, etkinlik ve yeterliliklerini belirlemeye yönelik geçerli ve güvenilir bir ölçek geliştirmeyi amaçlamışlardır. 520 fen bilgisi öğretmeninden elde edilen verilerin açımlayıcı ve doğrulayıcı faktör analizi sonucunda 24 madde ve dört boyuttan (tutum, davranış, etkinlik, yeterliliklerini) oluşan “Öğretmenler için Okul Dışı Öğrenme Ortamları Ölçeği" elde edilmiştir. Bir diğer ölçek ise Bolat ve Köroğlu (2020) tarafından geliştirilen “Okul Dışı Öğrenmeyi Düzenleme Ölçeği”dir. Ölçek farklı branşlarda görev yapan 340 öğretmenden alınan veriler ile geliştirilmiştir. Ölçek 29 madde ve dört faktörden oluşmaktadır. Ölçek faktörleri Bilgi, Planlama, Uygulama ve Değerlendirme'dir. Adıyaman ve Ünal (2020) öğretmen adaylarının algın öğrenme ortamlarına ilişkin görüşlerini belirlemek amacıyla "Algın Öğrenme Ortamları Ölçeği” gelişirmişlerdir. Araştırmada algın öğrenme ortamları olarak sosyal kulüpler, kamplar, sivil toplum kuruluşları, müzeler, bilim merkezleri, hayvanat bahçeleri, botanik parklar sergiler, sanayi kuruluşları, vb. tanımlanmıştır. 1103 öğretmen adayından elde edilen verilerle geliştirilen ölçek tek boyutlu ve 10 maddeden oluşmaktadır.

Bu çalışmada geliştirilen ölçek, ölçmek istediği amaç ve çalışma grubu açısından daha önce geliştirilen ölçeklerden farklılıklar içermektedir. Çalışma grubu olarak öğretmenlerin belirlenmesi, branş ayrımı yapılmaması, okul dışı öğrenmenin yalnızca ortamla sınılandırılmayıp bir faaliyet olarak ele alınması, kurumsal yapısının Bandura'nın $(1977,1994,1997)$ ortaya koymuş olduğu özyeterlik inançları şeklinde belirlenmesi bu ölçeği diğerlerinden farklı kılmaktadır.

\section{Araştırmanın Amacı}

Bu araştırmanın amacı “Okul Dışı Öğrenme (ODÖ) Faaliyetlerine Yönelik Öğretmen Özyeterlik İnançları Ölçeği“ geliştirmektir. 


\section{Yöntem}

Araştırma tarama modelinde, betimsel bir araştırmadır. Tarama, bir grubun belirli özelliklerini belirlemek için verilerin elde edildiği modeldir (Fraenkel, Wallen ve Hyun, 2012). Bu araştırmada öğretmenlerin ODÖ faaliyetlerine yönelik öz-yeterlik inançlarının belirlenebilmesi için, ölçek geliştirilme sürecinin aşamaları takip edilmiştir (Crocker ve Algina, 1986; DeVellis, 2017; Tezbaşaran, 1997). Araştırma, Bandırma Onyedi Eylül Üniversitesi, Sosyal ve Beşeri Bilimler Etik Kurulunun 18.06.2020 tarihli 2020-3 numaralı kararı ile gerçekleştirilmiştir.

\section{Çalışma Grubu}

Bu araştırmanın çalışma grubu 332 öğretmenden oluşmaktadır. Tablo 1'de 332 öğretmenin cinsiyet ve okul türüne göre dağılımları yer almaktadır.

Tablo 1. Öğretmenlerin Demografik Değişkenlere Göre Dağılımı

\begin{tabular}{llll}
\hline Değişken & & Frekans $(f)$ & Yüzde\% \\
\hline Cinsiyet & Kadın & 201 & 60,5 \\
& Erkek & 131 & 39,5 \\
\hline Okul Türü & Okul Öncesi & 11 & 3,3 \\
& İlkokul & 85 & 25,6 \\
& Ortaokul & 112 & 33,7 \\
& Lise & 98 & 29,5 \\
& Bilsem & 26 & 7,8 \\
\hline
\end{tabular}

Tablo 1 incelendiğinde araştırmaya katılan öğretmenlerin \%61‘ini kadınlar oluştururken $\% 40^{\prime} ı n ı$ ise erkekler oluşturmaktadır. Branşa göre dağılımlar incelendiğinde, öğretmenlerin çoğunlukla ilkokul, ortaokul ve lise kademelerinde görev yaptığı görülmektedir. 332 olan örneklem büyüklügüu açımlayıcı faktör analizi ve doğrulayıcı faktör analizi için yeterli görülmektedir (Cattell, 1978; Comrey ve Lee, 1992). Covid 19 pandemisi sebebiyle ikinci bir gruba uygulama yapma imkânı olmadığından aynı veriler üzerinden Doğrulayıcı Faktör Analizi (DFA) yapılmış ve bileşik güvenirlik katsayısı hesaplanmıştır. Bu durum araştırmanın sınırlılığını oluşturmakla birlikte Van Prooijen ve Van Der Kloot (2001), AFA ve DFA'nın aynı verilere uygulandıklarında aynı sonuçları vermesi gerekliliği üzerinde durmaktadır. DFA'nın aynı veri seti üzerindeki AFA sonuçlarını doğrulayamaması durumunda, AFA sonuçlarının başka bir bağımsız örneklemde doğrulanma şansının küçük olacağı öne sürülmüştür. Ayrıca, aynı verilere DFA'nın uyumu (veya uyumsuzluğu) hakkındaki bilgiler, yeni verilerle ilgili sonraki DFA için yararlı bilgiler sağlayabileceğini belirtmektedir.

\section{ODÖ Faaliyetine Yönelik Tutum Ölçeğinin Geliştirilme İşlemleri}

Farklı araştırmacılar tarafından ölçek geliştirilme sürecinde takip edilmesi gereken birbirine benzer işlem adımları tanımlanmıştır (Crocker ve Algina, 1986; DeVellis, 2017; Tezbaşaran, 1997). Bu araştırmanın ölçek geliştirme sürecinde aşağıdaki adımlar takip edilmiştir. 


\section{Ölçülecek Yapıyı Hedef Alan Davranışların Tanımlanması:}

Ölçek maddeleri oluşturulurken ODÖ faaliyetinin hazırlaması, uygulanması, değerlendirilmesi (Şen, 2019) ile öğrenmeyi destekleme yapıları temele alınmıştır. Ayrıca maddeler yazılırken Bandura'nın (1997) öz-yeterlik inançlarına yönelik kuramsal yapı göz önünde bulundurulmuştur.

\section{Madde Havuzunun Oluşturulması:}

$\mathrm{Bu}$ aşamada ilgili literatür taranarak özyeterlik inançları ve ODÖ ile ilişkili çalışmalarda kullanılan ölçme araçları ve nitel araştırmalar incelenmiştir. Daha sonra 10 öğretmene konuyla ilgili duygu, düşünce ve deneyimlerini yansıtan bir kompozisyon yazmaları istenmiştir. Sonuç olarak hem kompozisyonlar hem de ilgili alanyazın dikkate alınarak 40 maddelik bir madde havuzu oluşturulmuştur. Ölçekte yer alan ifadeler için "1= Hiç Katılmıyorum, 2= Katılmıyorum, 3= Biraz Katılıyorum, 4= Büyük Ölçüde Katılıyorum, 5= Tamamen Katılıyorum" şeklinde beşli Likert tipi bir derecelendirme kullanılmıştır.

\section{Kapsam ve Görünüş̧ Geçerliğinin Sağlanması:}

Ölçeğinin kapsam geçerliğini sağlamak için bir ölçme değerlendirme uzmanı, üç eğitim programları ve öğretimi uzmanı, bir matematik öğretmeni ve bir fen ve teknoloji öğretmeni olmak üzere altı uzman görüşüne başvurulmuştur. Kapsam geçerliliği test edilirken uzmanlara dörtlü likert tipindeki (1=Hiç uygun değil, 2=Majör revizyon gerekli, 3=Minör revizyon gerekli, 4= Tamamen Uygun) uzman görüş formu verilmiştir. Uzmanların tamamının bir ve iki puan verdikleri altı madde ölçekten çıkarılmış, üç madde ise düzeltilmiştir. Daha sonra düzeltilen bu maddelerden biri de uzman görüşleri doğrultusunda çıkarılmıştır. Son olarak ölçeğin 33 maddelik formu bir Türkçe öğretmeni tarafından dil ve görünüş geçerliliğinin sağlanması açısından gözden geçirilmiştir.

\section{Ön Deneme ve Asıl Uygulama:}

Asıl uygulamada ortaya çıkabilecek sıkıntıları en az seviyeye indirmek amacıyla 10 öğretmene ön uygulama yapılmıştır. Ön deneme sonucunda ölçeğin kaç dakikada yapıldığı, anlaşılmayan madde olup olmadığı sorulmuştur. Öğretmenlerden alınan dönütler sonucunda 17 olumsuz ve 16 olumlu olmak üzere toplamda 33 maddeden oluşan ölçek asıl uygulamaya alınmıştır.

\section{Veri Analizi:}

Olumsuz maddeler ters puanlanmak üzere, bilgisayar ortamına aktarılmıştır. Veri analizinde SPSS 22 ve LISREL 8.80 programı kullanılmıştır. Öğretmenlerden elde edilen veriler üzerinden Açımlayıcı Faktör Analizi (AFA) yapılmış, Cronbach Alfa katsayısı hesaplanmış ve madde analizleri yapılmıştır. Aynı veriler üzerinden Doğrulayıcı Faktör Analizi (DFA) yapılmış ve bileşik güvenirlik katsayısı hesaplanmıştır. 


\section{Bulgular}

\section{Yapı Geçerliği}

ODÖ Faaliyetlerine Yönelik Öğretmen Özyeterlik İnançları Ölçeği'nden elde edilen ölçümlerin yapı geçerliğini test etmek amacıyla AFA ve DFA uygulanmıştır.

\section{Açımlayıcı Faktör Analizi (AFA):}

AFA analizine başlamadan önce ilk olarak verilerin faktör analizine uygunluğunu tespit etmek amacıyla Kaiser-Meyer Olkin (KMO) örneklem yeterliliği değeri hesaplanmış ve .926 bulunmuştur. Elde edilen değer örneklem büyüklüğünün "mükemmel" düzeyde yeterli olduğunu göstermektedir (Hutcheson ve Sofroniou, 1999'dan aktaran Field, 2009, s. 647). Bartlett küresellik testinin istatistiksel olarak anlamlı olduğu $(\chi 2=6770,743, s d=528, p=.000)$ belirlenmiştir. Dolayısıyla değişkenler arasında yüksek korelasyonların bulunduğunu ve veri setinin temel bileşenler analizi için uygun olduğu söylenebilir (Kalaycı, 2006, s. 327). Bu tespitin ardından maddelerin hangi boyutlar altında gruplanacağını saptamak (Çokluk, Şekercioğlu ve Büyüköztürk, 2012) amacıyla AFA'da temel bileşenler analizi tekniği ve varimax döndürme yöntemi uygulanmıştır. AFA'da, faktör sayısına her ilave faktörün toplam varyansın açıklanmasına katkısı \%5'in altına düştüğünde maksimun faktör sayısına ulaşıldığını kabul eden toplam varyansın yüzdesi yöntemi, yamaç birikinti grafiği (Dunteman, 1989'dan aktaran Kalaycı, 2006, s. 322) ve Monte Carlo simülasyonuna dayalı paralel analiz yöntemi (Pallant, 2015), birlikte değerlendirilerek karar verilmiştir.

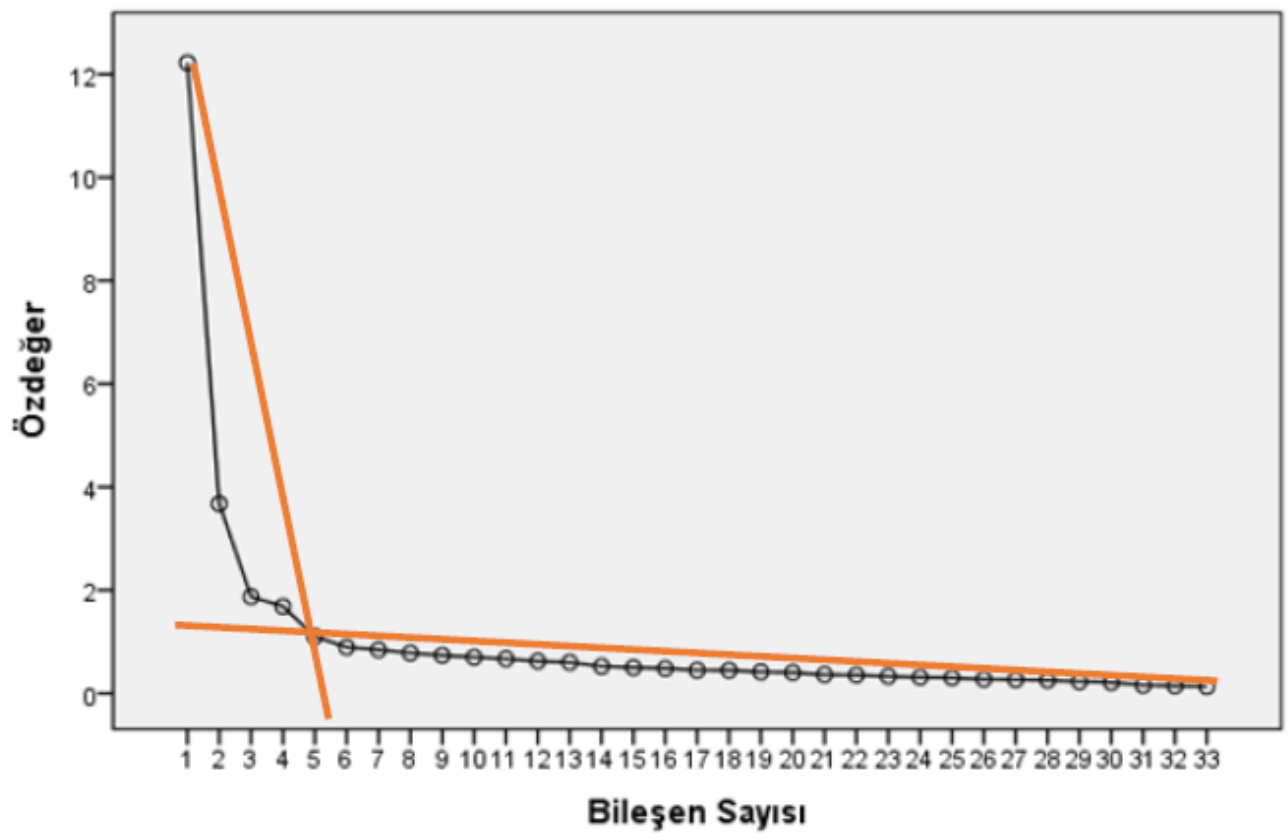

Şekil 1. Ölçeğin Yamaç-Birikinti Grafiği

Şekil 1' de yamaç birikinti grafiğinin bükülme noktasının sol tarafında kalan nokta sayısı faktör sayısını vermektedir (Field, 2009). Yamaç birikinti grafiğine göre faktör sayısı dört olarak 
gözükmektedir. Tablo 2'de özdeğeri 1'den büyük faktörler ve açıklanan toplam varyansları verilmiştir.

Tablo 2. Açıklanan Varyans Toplamı

\begin{tabular}{ccccccc}
\hline & \multicolumn{3}{c}{ Başlangıç Özdeğerleri } & \multicolumn{3}{c}{ Yüklerin Kareleri Toplamı (Extraction) } \\
\cline { 2 - 6 } Bileşen & Toplam & Varyans \% & Kümülatif \% & Toplam & Varyans \% & Kümülatif\% \\
\hline 1 & 12,223 & 37,039 & 37,039 & 12,223 & 37,039 & 37,039 \\
2 & 3,676 & 11,139 & 48,178 & 3,676 & 11,139 & 48,178 \\
3 & 1,873 & 5,675 & 53,853 & 1,873 & 5,675 & 53,853 \\
4 & 1,686 & 5,109 & 58,962 & 1,686 & 5,109 & 58,962 \\
5 & 1,102 & 3,341 & 62,303 & 1,102 & 3,341 & 62,303 \\
\hline
\end{tabular}

Tablo 2 incelendiğinde 4 . faktörden sonra, faktör sayısına her ilave faktörün toplam varyansın açıklanmasına katkısının \%5'in altına düştüğü görülmektedir. İlk dört faktörün toplam varyansın açıklanmasına katkısının \%5'in üzerinde olduğu tespit edilmiştir. Tablo 3'te Monte Carlo simülasyon programına değişken sayısı 33, katılımcı sayısı 332 ve tekrarlamanın sayısı 100 girilerek elde edilen özdeğerlerin, temel bileşenler analizinden elde edilen özdeğerler ile karşılaştırılması verilmiştir.

Tablo 3. Paralel Analizden Elde Edilen Kriter Değer ile Özdeğerlerin Karşılaştırılması

\begin{tabular}{cccc}
\hline Bileşen Numarası & Özdeğerler & Paralel Analiz Kriter Değer & Karar \\
\hline 1 & 12,223 & 1,6274 & Kabul \\
2 & 3,676 & 1,5574 & Kabul \\
3 & 1,873 & 1,4959 & Kabul \\
4 & 1,686 & 1,4717 & Kabul \\
5 & 1,102 & 1,3884 & Red \\
\hline
\end{tabular}

Tablo 3 incelendiğinde Monte Carlo PCA simülasyonuna dayalı olarak tesadüfi örneklem üzerinde paralel analiz işlemi gerçekleştirilmiştir. Yamaç-birikinti grafiği ve açıklanan varyans sonuçları ile paralel analiz sonuçları birlikte ele alındığında ölçeğin dört boyutlu yapısına işaret etmektedir. Gerçek özdeğerlerin beşinci faktöre kadar paralel analizden elde edilen özdeğerlerden büyük olduğu tespit edilmiş (Pallant, 2015) ve ilk dört faktör ölçeğin faktör sayısı olarak kabul edilmiştir.

Faktör analizinde aynı yapıyı ölçmeyen maddelerin elenmesinde üç temel ölçüt dikkate alınmıştır. Bunlardan birincisi maddenin bulunduğu faktördeki faktör yük değerinin alt kesme noktasının .30 ve üzeri olmasıdır (Büyüköztürk, 2019; Pallant, 2015). Ancak .45 üzerinde olması seçim için daha iyi bir ölçü olarak belirlenmiştir (Büyüköztürk, 2019; Tabachnick ve Fidell, 2001). Bu araştırmada alt kesme noktası olarak .45 ölçüt alınmıştır. İkincisi, maddenin tek bir faktörde yüksek yük değerine sahip olmasıdır. Araştırmada yüksek iki yük değeri arasındaki fark en az .10 olarak tutulmuştur (Büyüköztürk, 2019). Bu ölçüte uymayan 7., 10. ve 12. maddeler ölçekten çıkarılmıştır. Üçüncüsü ise maddelerin faktör yüklerinin yanı sıra ölçülen değişkene ait ortak varyans değerleri $\left(\mathrm{h}^{2}\right)$ de dikkate alınmasıdır. Faktör analizinde, Şencan (2005) .20'nin altında ortak varyansa sahip olan maddelerin ölçme aracından çıkarılması gerektiği ifade edilmektedir. Kalan maddelerin bu kritere uyduğu tespit edilmiştir. Bununla birlikte madde toplam korelasyonu .30 ve üstünde olan maddeler 
iç tutarlığının yüksek olduğunu göstermektedir (Büyüköztürk, 2019). Bu kapsamda madde toplam korelasyonu .30 altında olan ve ölçek güvenirliği düşüren 2. madde de ölçekten çıkarılmıştır.

Sonuç olarak ODÖ faaliyetlerine yönelik öğretmen öz-yeterlik inançları ölçeğinin belirtilen ölçütlere uymayan maddeleri çıarıldıktan sonra elde edilen dört faktörlü yapısı, faktör yükleri, ortak varyans değerleri, açılanan varyans ve özdeğerleri Tablo 4 'te verilmiştir.

Tablo 4. ODÖ Faaliyetlerine Yönelik Öğretmen Öz-Yeterlik İnançları Ölçeğinin Bileşen Yapısı ve Maddelerin Bileşen Yükleri

\begin{tabular}{|c|c|c|c|c|c|c|c|}
\hline 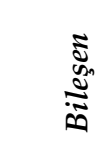 & 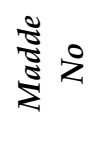 & 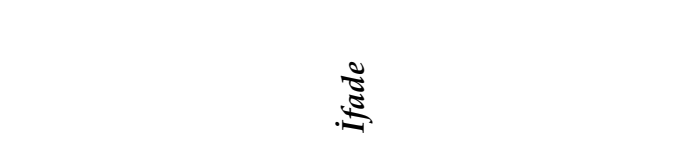 & $\frac{\sqrt{1}}{\sqrt[5]{5}}$ & 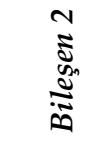 & 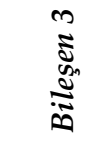 & 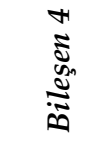 & $\Xi$ \\
\hline \multirow{13}{*}{ 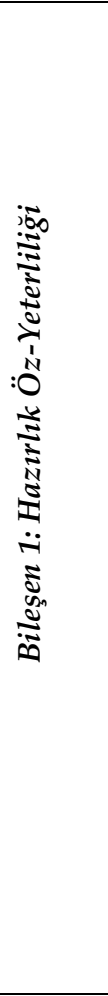 } & OY27 & ODÖ faaliyeti düzenleyebilirim. & ,805 & 203 & 187 & 103 & 73 \\
\hline & OY17 & $\begin{array}{l}\text { ODÖ faaliyeti öncesi karşıma çıkan engelleri } \\
\text { aşabilirim. }\end{array}$ & ,802 & ,126 & ,058 & ,112 & 67 \\
\hline & OY18 & $\begin{array}{l}\text { Yasal prosedürleri gözeterek ODÖ faaliyeti } \\
\text { düzenleyebilirim. }\end{array}$ & ,773 & 163 & ,087 & ,122 & 65 \\
\hline & OY22 & $\begin{array}{l}\text { ODÖ faaliyeti sırasında karşılaşabileceğim } \\
\text { olumsuzluklarla baş edebilirim. }\end{array}$ & ,770 & ,209 & 100 &,- 002 & 65 \\
\hline & OY16 & $\begin{array}{l}\text { ODÖ faaliyetine yönelik gerekli izin ve } \\
\text { işlemleri yürütebilirim. }\end{array}$ & ,762 & ,194 & ,225 & ,054 & 67 \\
\hline & OY15 & $\begin{array}{l}\text { ODE faaliyeti öncesinde ilgili kişilere gerekli } \\
\text { bilgilendirmeleri yapabilirim. }\end{array}$ & ,757 & 188 & ,261 & 129 & 69 \\
\hline & OY26 & $\begin{array}{l}\text { ODÖ faaliyeti sırasında aktif bir rol } \\
\text { üstlenebilirim. }\end{array}$ & 743 & 234 & 0,21 &,- 002 & 65 \\
\hline & OY14 & $\begin{array}{l}\text { ODÖ faaliyetine yönelik plan ve hazırlıkları } \\
\text { yapabilirim. }\end{array}$ & 729 & 198 & 157 & 204 & 64 \\
\hline & OY28 & $\begin{array}{l}\text { ODÖ faaliyetinin ne olduğunu etkili bir şekilde } \\
\text { gerçekleştirecek kadar iyi biliyorum. }\end{array}$ & ,694 & 119 & 119 & 4 & 67 \\
\hline & OY20 & $\begin{array}{l}\text { ODÖ faaliyeti öncesinde yaşanabilecek } \\
\text { güvenlik sorunlarını öngörebilirim. }\end{array}$ & ,611 &,- 012 & 195 & 138 & 043 \\
\hline & OY31 & $\begin{array}{l}\text { ODÖ faaliyeti sırasında öğrencilerin sorularını } \\
\text { rahatlıkla cevaplayabilirim. }\end{array}$ & ,596 & ,241 & ,229 & ,091 & ,47 \\
\hline & & Açıklanan Varyans \% & 23,6 & & & & \\
\hline & & Özdeğer & 6,89 & & & & \\
\hline \multirow{6}{*}{ 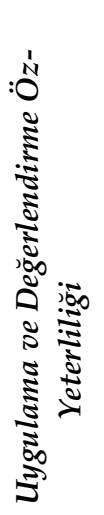 } & OY24 & $\begin{array}{l}\text { *ODÖ faaliyeti sırasında güvenliği sağlamakta } \\
\text { zorluk yaşarım. }\end{array}$ & 175 & 786 & ,009 & ,101 & ,66 \\
\hline & OY23 & $\begin{array}{l}\text { *ODÖ faaliyeti sürecinde yaşadığım stresle baş } \\
\text { etmekte zorlanırım. }\end{array}$ & 109 & 757 & 0066 & 146 & 61 \\
\hline & OY21 & $\begin{array}{l}\text { *ODÖ faaliyeti sırasında grubun kontrolünü } \\
\text { sağlamakta zorlanırım. }\end{array}$ & ,225 & ,747 &,- 043 & ,005 & ,61 \\
\hline & OY25 & $\begin{array}{l}\text { *ODÖ faaliyeti sırasında öğrencilerin dikkatini } \\
\text { toplamakta zorluk çekerim. }\end{array}$ & 195 & 728 & 192 & ,087 & 61 \\
\hline & OY19 & $\begin{array}{l}\text { *ODÖ faaliyeti konusunda ilgili kişi ve } \\
\text { kurumlarla görüşmeye çekinirim. }\end{array}$ & 182 & 695 & ,14 & ,053 & ,54 \\
\hline & OY30 & $\begin{array}{l}\text { *ODÖ faaliyeti sırasında öğrencilere gerekli } \\
\text { açıklamaları yapmakta güçlük yaşayabilirim. }\end{array}$ & 073 & 657 & 221 & 118 & ,50 \\
\hline \multirow{2}{*}{ 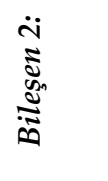 } & OY32 & $\begin{array}{l}\text { *ODÖ faaliyeti konusunda sorumluluk } \\
\text { almaktan kaçınırım. }\end{array}$ & 161 & 653 & 129 & 167 & ,50 \\
\hline & OY33 & $\begin{array}{l}\text { *ODÖ faaliyetlerini değerlendirmekte } \\
\text { zorlanırım }\end{array}$ & 204 & 628 & 106 & 266 & ,52 \\
\hline
\end{tabular}




\begin{tabular}{|c|c|c|c|c|c|c|c|}
\hline & OY29 & $\begin{array}{l}\text { *ODÖ faaliyetini etkili bir şekilde } \\
\text { gerçekleştiremeyebilirim. }\end{array}$ & , 075 & ,623 & 132 & ,118 & ,43 \\
\hline & OY13 & $\begin{array}{l}\text { *ODÖ faaliyetine öğrenci katılımın sağlanması } \\
\text { için velileri ikna etmekte zorlanırım. }\end{array}$ & ,131 &, 554 &,- 082 & ,343 & ,45 \\
\hline & & Açıklanan Varyans \% & 19,3 & & & & \\
\hline & & Özdeğer & 5,60 & & & & \\
\hline \multirow{6}{*}{ 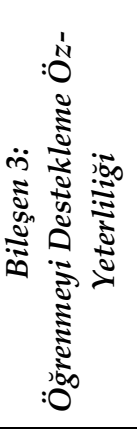 } & OY4 & $\begin{array}{l}\text { ODÖ faaliyeti ile öğrenmenin kalıcılığını } \\
\text { arttırabilirim. }\end{array}$ & ,311 & 106 & ,804 & ,113 & ,77 \\
\hline & OY6 & $\begin{array}{l}\text { ODÖ faaliyetleri ile öğrencilerde ilgi ve merak } \\
\text { uyandırabilirim. }\end{array}$ & ,255 & ,236 & ,783 & -,114 & ,75 \\
\hline & OY5 & $\begin{array}{l}\text { ODÖ faaliyeti ile öğrencilere üst düzey } \\
\text { beceriler kazandirabilirim. }\end{array}$ &, 34 & 135 & ,780 & ,118 & ,76 \\
\hline & OY3 & $\begin{array}{l}\text { ODÖ faaliyetleri ile ders kazanımlarını günlük } \\
\text { hayatla ilişkilendirebilirim. }\end{array}$ & ,428 & ,128 &, 595 & ,215 & ,60 \\
\hline & & Açıklanan Varyans \% & 9,68 & & & & \\
\hline & & Özdĕger & 2.81 & & & & \\
\hline \multirow{7}{*}{ 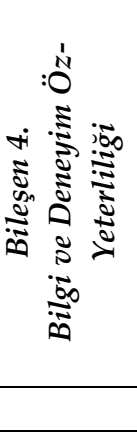 } & OY1 & $\begin{array}{l}\text { *Kazanımlara göre ODÖ faaliyeti hazırlamakta } \\
\text { zorlanırım. }\end{array}$ & ,095 & ,076 & ,113 & ,715 &, 54 \\
\hline & OY8 & $\begin{array}{l}\text { *Alanımla ilgili ODÖ faaliyeti düzenlemekte } \\
\text { zorlanırım. }\end{array}$ & ,088 & 34 & ,222 & ,697 & ,66 \\
\hline & OY9 & *ODÖ konusunda yeterli bilgiye sahip değilim. & ,288 & ,358 &,- 059 & 632 & ,61 \\
\hline & OY11 & $\begin{array}{l}\text { *ODÖ faaliyeti gerçekleştirme konusunda } \\
\text { tecrübesizim. }\end{array}$ & ,344 & 411 &,- 081 & ,604 & ,66 \\
\hline & & Açıklanan Varyans \% & 8,34 & & & & \\
\hline & & Özdeğger & 2,42 & & & & \\
\hline & & Toplam Açıklanan Varyans & 61,0 & & & & \\
\hline
\end{tabular}

Tablo 4 incelediğinde ölçeğin 14 olumsuz, 15 olumlu madde olmak üzere toplam 29 maddeden oluştuğu görülmektedir. Temel bileşenler analizi sonucunda 29 maddenin 4 bileşenden oluştuğu tespit edilmiştir. Maddelerin içerikleri ve kuramsal yapı dikkate alınarak, 11 maddeden oluşan bileşen 1; "Hazırlık Öz-yeterliliği", 10 maddeden oluşan bileşen 2; "Uygulama ve Değerlendirme Öz-yeterliliği", 4 maddeden oluşan bileşen 3; “Öğrenmeyi Destekleme Öz-yeterliliği” ve 4 maddeden oluşan bileşen 4; "Bilgi ve Deneyim Öz-yeterliliği" olarak adlandırılmıştır. Bileşen 1'de maddelerinin aldıkları yükler .805 ile .596 arasında değişmektedir ve toplam varyansın \%23,68'ini açılamaktadır. Bileşen 2 maddelerinin aldıkları yükler .786 ile .554 arasında değişmektedir ve toplam varyansa \%19,60 katkı sağlamaktadır. Bileşen 3 maddelerinin aldıkları yükler .804 ile .595 arasında değişmektedir ve toplam varyansa \%9,68 katkı sağlamaktadır. Bileşen 4 maddelerinin aldıkları yükler .715 ile .604 arasında değişmektedir ve toplam varyansın \%8,34'ünü açıklamaktadır. Ölçeğin açıklanan toplam varyansı ise $\% 43.401^{\prime}$ dir.

\section{Doğrulayıcı Faktör Analizi (DFA):}

AFA sonucunda elde edilen 29 madde ve dört faktörden oluşan yapıyı doğrulayıp doğrulamadığını test etmek için verilere DFA uygulanmıştır. Şekil 2' de görüldüğü gibi 29 madde ile bu maddelerin ölçmeye yöneldiği dört farklı yapı arasındaki standartlaştırılmış faktör yükleri 0.40 ve üzerinde olduğu tespit edilmiştir. 


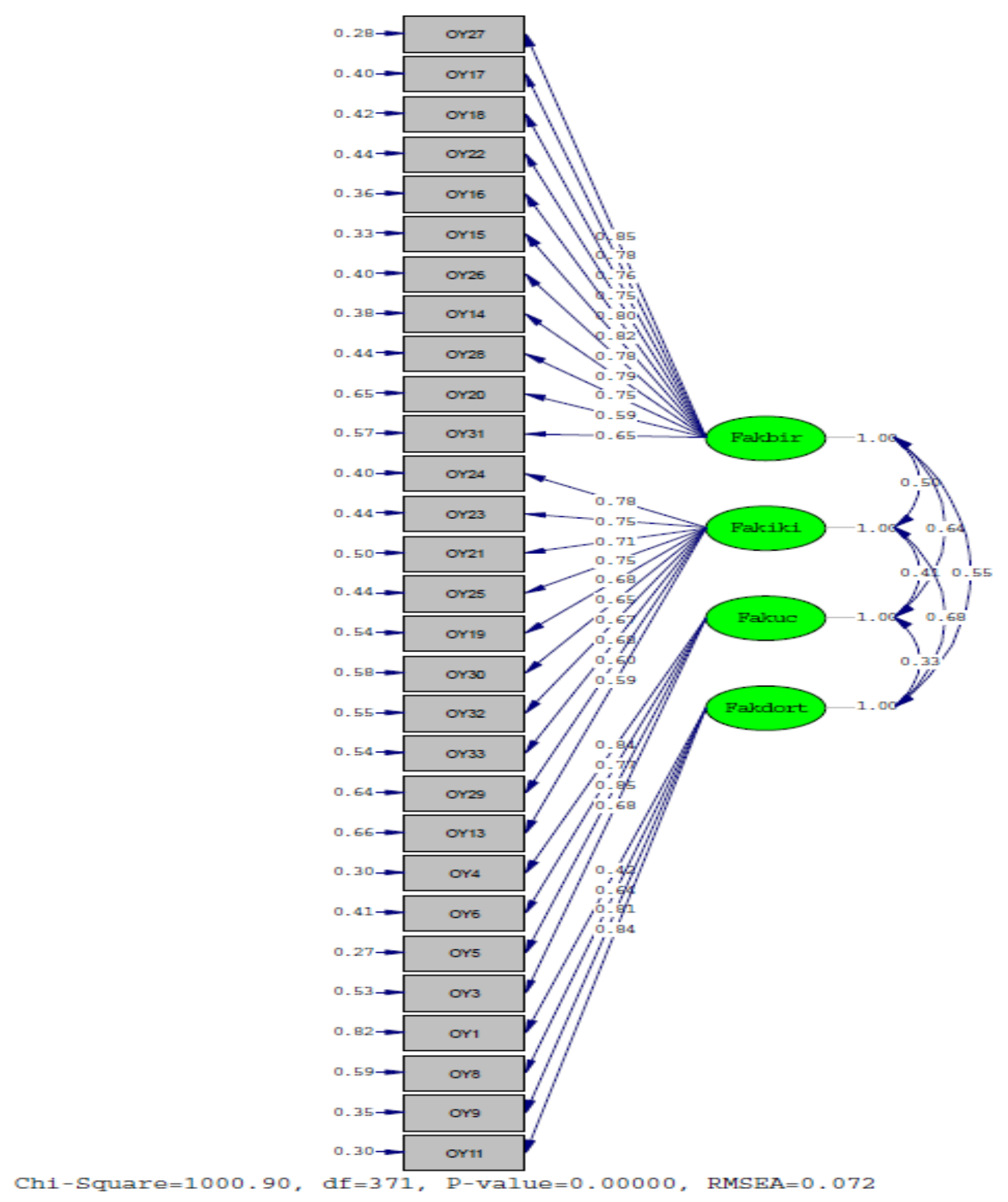

Şekil 2. Standartlaştırılmış DFA Çözümleri

ODÖ Faaliyetlerine Yönelik Öğretmen Öz-yeterlik İnançları Ölçeği'ne ilişkin DFA'dan elde edilen uyum indeksi değerleri, uyum indekslerine ilişkin kabul edilebilir ve mükemmel uyum değerlerine yönelik kriterler (Hu ve Bentler, 1999; Meydan ve Şeşen, 2011; Meyers, Gamst ve Guarino, 2006; Schermelleh-Engel ve Moosbrugger, 2003; Schumacker ve Lomax, 2004; Seçer, 2015; Tabachnick ve Fidel, 2001) ve sonuçları Tablo 5'te gösterilmiştir. 
Tablo 5: Model Uyumuna İlişkin Referanslar ve Model Uyum İndeksleri

\begin{tabular}{|c|c|c|c|c|}
\hline $\begin{array}{l}\text { Uyum } \\
\text { Indeksleri }\end{array}$ & $\begin{array}{l}\text { Mükemmel Uyum } \\
\text { Kriterleri (MU) }\end{array}$ & $\begin{array}{l}\text { Kabul Edilebilir Uyum } \\
\text { Kriterleri }(K U)\end{array}$ & $\begin{array}{l}\text { Elde Edilen } \\
\text { Uyum } \\
\text { İndeksleri }\end{array}$ & Sonuç \\
\hline$\chi 2 / s d$ & $0 \leq \chi 2 / s d \leq 2$ & $2 \leq \chi 2 / s d \leq 3$ & 0.27 & KU \\
\hline CFI & $.95 \leq \mathrm{CFI} \leq 1.00$ & $.90 \leq \mathrm{CFI} \leq .95$ & .97 & $\mathrm{MU}$ \\
\hline NFI & $.95 \leq \mathrm{NFI} \leq 1.00$ & $.90 \leq \mathrm{NFI} \leq .95$ & .95 & MU \\
\hline NNFI & $.95 \leq \mathrm{NNFI} \leq 1.00$ & $.90 \leq \mathrm{NNFI} \leq .95$ & .96 & MU \\
\hline IFI & $.95 \leq \mathrm{IFI} \leq 1.00$ & $.90 \leq \mathrm{IFI} \leq .95$ & .97 & MU \\
\hline RFI & $.90 \leq \mathrm{RFI} \leq 1.00$ & $.85 \leq \mathrm{RFI} \leq .90$ & .94 & MU \\
\hline RMSEA & $.00 \leq$ RMSEA $\leq .05$ & $.05 \leq$ RMSEA $\leq .08$ & .07 & KU \\
\hline SRMR & $.00 \leq$ SRMR $\leq .05$ & $.05 \leq$ SRMR $\leq .10$ & .06 & KU \\
\hline PNFI & $.95 \leq \mathrm{PNFI} \leq 1.00$ & $.50 \leq \mathrm{PNFI} \leq .95$ & .87 & KU \\
\hline PGFI & $.95 \leq$ PGFI $\leq 1.00$ & $.50 \leq$ PGFI $\leq .95$ & 0.7 & KU \\
\hline
\end{tabular}

Tablo 5'teki ODÖ faaliyetlerine yönelik öğretmen özyeterlik inançları ölçeğinin uyum indeksi değerleri $\mathrm{CFI}=.97, \mathrm{NFI}=.90, \mathrm{NNFI}=.95, \mathrm{IFI}=.97, \mathrm{RFI}=.94$ mükemmel uyuma karşıllık gelmekte iken; $\chi 2 / \mathrm{sd}=0,27, \mathrm{RMSEA}=.072$, SRMR $=.06, \mathrm{PNFI}=.87$ ve PGFI $=.7$ değerleri kabul edilebilir uyuma karşılık gelmektedir. Dolayısıyla DFA'dan elde edilen dört faktörlü modelin uyum düzeyinin yeterli olduğu söylenebilir. DFA sonucu elde edilen dört faktörlü modele ilişkin t-testi değerleri ise Tablo 6'da sunulmuştur.

Tablo 6. DFA'dan Elde Edilen T-Testi Değerleri

\begin{tabular}{clllllll}
\hline $\begin{array}{l}\text { Madde No/ } \\
\text { Bileşen 1 }\end{array}$ & $\boldsymbol{t}$ & $\begin{array}{l}\text { Madde No/ } \\
\text { Bileşen 2 }\end{array}$ & $\boldsymbol{t}$ & $\begin{array}{l}\text { Madde No/ } \\
\text { Bileşen 3 }\end{array}$ & $\boldsymbol{t}$ & $\begin{array}{l}\text { Madde No/ } \\
\text { Bileşen 4 }\end{array}$ & $\boldsymbol{t}$ \\
\hline OY27 & 19.02 & OY24 & 16.36 & OY4 & 17.98 & OY1 & 17.48 \\
OY17 & 16.59 & OY23 & 15.47 & OY6 & 15.88 & OY8 & 12.09 \\
OY18 & 16.20 & OY21 & 14.41 & OY5 & 18.45 & OY9 & 16.44 \\
OY22 & 15.74 & OY25 & 15.42 & OY3 & 13.52 & OY11 & 17.30 \\
OY16 & 17.27 & OY19 & 13.64 & & & & \\
OY15 & 17.93 & OY30 & 12.74 & & & & \\
OY26 & 16.61 & OY32 & 13.36 & & & & \\
OY14 & 16.87 & OY33 & 13.57 & & & & \\
OY28 & 15.64 & OY29 & 11.53 & & & & \\
OY20 & 11.56 & OY13 & 11.27 & & & & \\
OY31 & 13.13 & & & & & &
\end{tabular}

Tablo 6'ya göre t-testi değerlerinin 11.27 ile 19.02 arasında değiştiği görülmektedir. Anlamlı olmayan $t$ değerinin bulunmaması modelden madde çıkarılmasına gerek olmadığını göstermektedir (Çokluk vd., 2018). t istatistiklerine bakıldığında her bir bileşenin altında yer alan maddenin, bileşenle uyumlu olduğu sonucuna ulaşılmıştır. 


\section{Güvenirlik}

ODÖ faaliyetlerine yönelik öğretmen öz-yeterlik inançları ölçeğine ait ölçümlerin güvenirliği, Cronbach Alfa ve bileşik güvenirlik sonuçları değerlendirilmiştir. Elde edilen değerler Tablo 7 'de verilmiştir.

Tablo 7. Güvenirlik Katsayıları

\begin{tabular}{lccc}
\hline Alt Ölçekler & $\begin{array}{c}\text { Madde } \\
\text { Sayısı }\end{array}$ & Cronbach's Alpha & $\begin{array}{c}\text { Bileşik } \\
\text { Güvenirlik }\end{array}$ \\
\hline Bileşen 1 & 11 & .95 & .94 \\
Bileşen 2 & 10 & .90 & .90 \\
Bileşen 3 & 4 & .86 & .87 \\
Bileşen 4 & 4 & .78 & .78 \\
Ölçek Geneli & 29 & .94 & .97 \\
\hline
\end{tabular}

Ölçümlerin Cronbach Alpha güvenirlik katsayıları bileşen 1 için .95; bileşen 2 için .90; bileşen 3 için .86; bileşen 4 için .78 ve ölçek geneli için .94 olduğu görülmüştür. Bileşik güvenirliklerinde .78 ile .94 arasında olduğu tespit edilmiştir. Sonuç olarak güvenirlik katsayısı .70 ve üzerinde olan ölçümlerin güvenilir kabul edildiği (Field, 2009; Fraenkel vd., 2012) ölçütü dikkate alındığında, güvenirlik katsayılarının yeterli olduğu söylenebilir. Ölçekten toplam puanın elde edilip edilemeyeceğinin belirlenmesi amacıyla yapılan Tukey Nonadditivity testi sonucunda, ölçeğin toplanabilir özellikte olduğu tespit edilmiştir (Tukey Nonadditivity: F=.100, p=.751>0.05).

\section{Madde Analizi}

Maddelerinin ayırt edicilik düzeylerini ve toplam puanı yordama gücünü belirlemek amacıyla madde analizi yapılmıştır. Bu kapsamda madde toplam korelasyonu hesaplanmış ve \%27'lik alt-üst grup karşılaştırmalarına yer verilmiştir. Madde analizi sonucunda elde edilen bulgular Tablo 8'de gösterilmiştir.

Tablo 8. Madde Analizi Sonuçları

\begin{tabular}{lcccc}
\hline $\begin{array}{l}\text { Madde } \\
\text { No }\end{array}$ & $\begin{array}{c}\text { Madde-Toplam } \\
\text { Korelasyonu }\end{array}$ & $\begin{array}{c}\text { Madde Silinirse } \\
\text { Cronbach Alpha }\end{array}$ & $t$ & $p$ ve df \\
\hline OY27 &, 824 &, 926 & $-17,051$ & \\
OY17 &, 754 &, 929 & $-12,946$ & \\
OY18 &, 741 &, 929 & $-14,465$ & \\
OY22 &, 734 &, 930 & $-13,454$ & \\
OY16 &, 764 &, 928 & $-13,818$ & $\mathrm{df}=179$ \\
OY15 &, 785 &, 927 & $-16,553$ & $\mathrm{p}=0.00$ \\
OY26 &, 749 &, 929 & $-14,890$ & \\
OY14 &, 752 &, 929 & $-14,287$ & \\
OY28 &, 714 &, 931 & $-15,347$ & \\
OY20 &, 576 &, 936 & $-8,402$ & \\
OY31 &, 622 &, 934 & $-12,716$ & $\mathrm{df}=179$ \\
\hline OY23 &, 730 &, 882 & $-11,866$ & \\
OY21 &, 702 &, 884 & $-11,096$ & \\
OY25 &, 660 &, 886 & $-12,384$ & \\
OY19 &, 690 &, 885 & $-13,213$ & \\
OY30 &, 647 &, 887 & $-10,451$ & \\
OY32 &, 615 &, 889 & $-12,900$ & \\
\hline
\end{tabular}




\begin{tabular}{lllll} 
OY33 &, 638 &, 888 & $-13,023$ & \\
OY24 &, 643 &, 888 & $-11,498$ & \\
OY29 &, 580 &, 892 & $-8,756$ & \\
OY13 &, 548 &, 894 & $-9,647$ & \\
\hline OY4 &, 774 &, 829 & $-10,148$ & $\mathrm{df}=179$ \\
OY6 &, 704 &, 803 & $-9,905$ & $\mathrm{p}=0.00$ \\
OY5 &, 767 &, 865 & $-11,449$ & \\
OY3 &, 610 &, 795 & $-11,824$ & $\mathrm{df}=179$ \\
\hline OY1 &, 424 &, 705 & $-6,542$ & $\mathrm{p}=0.00$ \\
OY8 &, 611 &, 684 & $-10,359$ & \\
OY9 &, 654 &, 689 & $-12,378$ & \\
OY11 &, 640 & & &
\end{tabular}

Tablo 8 'deki bulgular incelendiğinde, \%27'lik alt ve üst grupların madde puanlarındaki farklara ilişkin $t$ değerlerinin anlamlı olması maddelerin ayırt ediciliği için bir kanıt olarak değerlendirilmektedir (Erkuş, 2012). Tablo 8'e göre bütün maddeler madde toplam korelasyonu değeri .30 ve üzerinde olduğu için ölçülecek özelliği ayırt etme açısından yeterli olduğu söylenebilir (Büyüköztürk, 2019; Kalayc1, 2006).

\section{Tartışma}

Yirmi birinci yüzyıl becerilerin öğrencilere kazandırılması sürecinde okul dışı öğrenme faaliyetlerinin etkisi oldukça önemlidir. Son yıllarda Türkiye Bilim ve Teknik Kurumunun Doğa Eğitimi ve Bilim Okulları adı altında okul dışı öğrenme faaliyetlerine yer veren projeleri desteklemesi, il milli müdürlükleri tarafından okul dışı öğrenme ortamlarına yönelik kılavuzlar hazırlanması (Milli Eğitim Bakanlığı [MEB], 2019) okul dışı öğrenme faaliyetlerine yönelik ilginin giderek arttığını göstermektedir. Bu doğrultuda araştırmada ODÖ faaliyetlerine yönelik öğretmen öz-yeterlik inançları ölçeğinin geliştirilmesi amaçlanmıştır.

Ölçek geliştirme çalışmasında uzman görüşleri doğrultusunda kapsam geçerliliği sağlanan ve 15 olumsuz 14 olumlu olmak üzere toplam 29 maddeden oluşan bir ölçek elde edilmiştir. Ölçek toplam varyansın \%61,01'ini açıklamaktadır. AFA sonucunda ölçeğin dört faktörlü bir yapıya sahip olduğu görülmüştür. Bu dört faktör sırasıyla, “Hazırlık Öz-yeterliliği”, “Uygulama ve Değerlendirme Öz-yeterliliği”, “Öğrenmeyi Destekleme Öz-yeterliliği” ve "Bilgi ve Deneyim Öz-yeterliliği” olarak adlandırılmıştır. DFA sonucunda ölçeğinin dört faktörlü yapısına ait uyum indekslerinin "kabul edilebilir uyum" ve "mükemmel uyum" düzeylerinde oldukları tespit edilmiştir. AFA ve DFA sonuçları ODÖ faaliyetlerine yönelik öğretmen öz-yeterlik inançları ölçeğinin yapı geçerliğinin sağlandığı göstermektedir. 
ODÖ faaliyetlerine yönelik öğretmen öz-yeterlik inançları ölçeğinden elde edilen ölçümlerin güvenirliği, Cronbach Alpha ve bileşik güvenirlik katsayıları ile ortaya konulmuştur. Ölçümlerin güvenirlik katsayıların dört faktör ve ölçek geneli için .78 ve üzerinde olduğu tespit edilmiştir. İlgili alan yazında 70 ve üzeri değer ölçümlerin güvenilir olduğunu göstermektedir (Büyüköztürk, 2019; Field, 2009; Fraenkel vd., 2012). Tukey's Test for Non-additivity sonuçları ölçeğin toplanabilir özellikte olduğunu göstermektedir.

ODÖ faaliyetlerine yönelik öğretmen öz-yeterlik inançları ölçeğinin madde analizinde madde toplam korelasyonu ve \%27'lik alt-üst grup karşılaştırmaları incelenmiştir. Analiz sonucunda, madde toplam korelasyonlarının .424 ve .824 arasında sıralandığ 1 ve $\% 27^{\prime}$ lik alt ve üst grup arasındaki farklara ilişkin $\mathrm{t}$ değerlerin ölçekte yer alan tüm maddeler için anlamlı olduğu belirlenmiştir. $\mathrm{Bu}$ bulgular, ODÖ faaliyetlerine yönelik öğretmen öz-yeterlik inançları ölçeği maddelerinin $t$ ayırt edici olduğunu göstermektedir. Yapılan ölçek geliştirme çalışması sonucunda, ODÖ faaliyetlerine yönelik öğretmen öz-yeterlik inançları ölçeğinin öğretmenlerin öz-yeterlik inançlarını belirlemede geçerli ve güvenilir ölçümler veren bir ölçme aracı olduğu tespit edilmiştir.

ODÖ faaliyetlerine yönelik öğretmen öz-yeterlik inançları ölçeği, Bozdoğan (2016) tarafından geliştirilen okul dışı çevrelere eğitim amaçlı gezi düzenleyebilme öz-yeterlik inancına yönelik ölçekten okul dışı öğrenmeyi sadece gezi şeklinde ele almamasıyla yönüyle farklılaşmaktadır. Balkan-Kıyıcı ve Yavuz-Topaloğlu (2016) tarafından geliştirilen “Öğretmenler için Okul Dışı Öğrenme Ortamları Ölçeği"nden sadece fen dersine yönelik olmaması ve bütün boyutlarının öz-yeterlik inancına yönelik olması bakımından farklılaşmaktadır. ODÖ faaliyetlerine yönelik öğretmen öz-yeterlik inançları ölçeği Bolat ve Köroğlu (2020) tarafından geliştirilen “Okul Dışı Öğrenmeyi Düzenleme Ölçeği” ile alt boyut isimlerinin benzer olması bakımından benzerlik göstermektir. Fakat bu araştırmadaki en büyük farklılık geliştirilen ölçeğin Bandura'nın (1977, 1994, 1997) ortaya koymuş olduğu öz-yeterlik inançları kuramsal yapısına dayandırılmasıdır.

\section{Sonuç}

Araştırma sonucunda; ODÖ faaliyetlerine yönelik öğretmen öz-yeterlik inançlarını belirlenmesini sağlayan ve 14'ü olumsuz 15'i olumlu olmak üzere toplam 29 maddeden oluşan bir ölçek geliştirilmiştir. Elde edilen sonuçlar ölçümlerin geçerli ve güvenilir olduğunu göstermektedir. ODÖ faaliyetlerine yönelik öğretmen öz-yeterlik inançları ölçeğinde, 11 maddeden oluşan "Hazırlık Öz-yeterliliği" boyutundan en az 11 en fazla 55 puan, 10 maddeden oluşan "Uygulama ve Değerlendirme Öz-yeterliliği” boyutundan en az 10 en fazla 50, 4 maddeden oluşan "Öğrenmeyi Destekleme Öz-yeterliliği" boyutundan en az 4 en fazla 20 ve 4 maddeden oluşan "Bilgi ve Deneyim Öz-yeterliliği" boyutundan ise en az 4 en fazla 20 puan alınabilir. Ölçek genelinde alınabilecek en az puan 29 en yüksek puan ise $145^{\prime}$ dir. Ölçeğin yapı geçerliği ve güvenirliği ile ölçek maddelerinin ayırt 
ediciliği için tek bir kanıt yerine birden fazla kanıt sunulması çalışmanın güçlü yönleri arasında yer almaktadır. Bununla birlikte aynı veri grubu üzerinde DFA analizlerinin yapılması sınırlılık olarak görülmektedir. Bu sebeple ilk olarak, araştırmacılara farklı bir öğretmen grubu üzerinde DFA analizini tekrarlamaları önerilir. Daha sonra yapılabilecek araştırmalara ilişkin bir diğer öneri, ODÖ faaliyetlerine yönelik öz-yeterlik inançları ölçeğinin uyum geçerliliği, benzerlik, yakınsak geçerlik ve ayırıcılık geçerliğinin de farklı çalışmalarla incelenmesi şeklinde olabilir. Ölçeğin güvenirliğine ilişkin test-tekrar test gibi farklı güvenirlik hesaplama yöntemleriyle çalışmalar yapılabilir.

\section{Kaynaklar}

Adıyaman, A., \& Ünal, F. (2020). Algın öğrenme ortamlarına yönelik öğretmen adayları görüşleri. Journal of Humanities and Tourism Research, 10(1), 95-114. doi: 10.14230/johut784

Andersson, C., \& Johansson, P. (2013). Social stratification and out-of-school learning. Journal of the Royal Statistical Society: Series A (Statistics in Society), 176(3), 679-701.

Andrew, M., Maggie, E., \& Sarah, B. (2010). Applied research and zoo education: The evolution and evaluation of a public talks program using unobtrusive video recording of visitor behavior. Visitor Studies, 13(1), 23-40.

Balkan-Kıyıcı, F., \& Atabek-Yiğit, E. (2010). Science education beyond the classroom: A field trip to wind power plant. International Online Journal of Science Education, 28(12), 1373-1388

Balkan-Kıyıcı, F., \& Yavuz-Topaloğlu, M. (2016). A Scale development study for the teachers on out of school learning environments. Malaysian Online Journal of Educational Sciences, 4(4), 1-13

Bandura, A. (1977). Self-efficacy: Toward a unifying theory of behavior change. Psychological Rewiew $84,191-215$.

Bandura, A. (1986). Social foundations of thought and action: A social cognitive theory. Englewood Cliffs, NJ: Prentice Hall.

Bandura, A. (1994). Self efficacy. V. S. Ramachaudran (Ed.), Encylopedia of human behavior içinde (s. 7181). New York: Academic Press.

Bandura, A. (1997). Self efficacy: The exercise of control. Newyork: Freeman

Berberoğlu, O. E., \& Uygun S. (2013). Sınıfdışı eğitimin dünyadaki ve Türkiye'deki gelişim durumunun örgün ve yaygın eğitim kapsamında incelenmesi. Mersin Üniversitesi Ĕgitim Fakültesi Dergisi, 9(2), 32-42

Bıkmaz, F. (2004). Öz yeterlik inançları. Y. Kuzgun, \& D. Deryakulu. (Ed.). Eğitimde bireysel farklılıklar içinde (s. 289-315). Ankara: Nobel Yayın.

Bolat, Y., \& Köroğlu, M. (2020). Out-of-school learning and scale of regulating out-of-school learning: Validity and reliability study, International Journal of Education Technology and Scientific 
Researches, 5(13), 1630-1663. http://ijetsar.com/DergiTamDetay.aspx?ID=258\&Detay=Ozet sayfasından erişilmiştir.

Bozdoğan, A. E. (2016). Okul dışı çevrelere eğitim amaçlı gezi düzenleyebilme öz-yeterlik inancı ölçeğinin geliştirilmesi. Kuramsal Eğitimbilim Dergisi [Journal of Theoretical Educational Science], 9(1), 111-129. http://dx.doi.org/10.5578/keg.9475

Büyüköztürk, Ş. (2019). Sosyal bilimler için veri analizi el kitabı (25. Baskı). Ankara: Pegem Akademi

Cattell, R. B. (1978). The scientific use of factor analysis in behavioral and life sciences. New York: Plenum

Comrey, A. L., \& Lee, H. B. (1992). A first course in factor analysis. Hillsdale, NJ: Lawrence Erlbaum Associates.

Crocker, L., \& Algina, J. (1986). Introduction to classical and modern test theory. Fort Worth, TX: Holt, Rinehart and Winston Inc.

Çokluk, Ö., Şekercioğlu, G., \& Büyüköztürk, Ş. (2012). Sosyal bilimler için çok değiş̧kenli istatistik: SPSS ve LISREL uygulamaları. Ankara: Pegem.

DeVellis, R. F. (2017). Scale development: Theory and applications (4th Ed.). Thousand Oaks CA: Sage.

Erkuş, A. (2012). Psikolojide ölçme ve ölçek geliştirme. Ankara: Pegem Akademi Yayınları

Ertaş, H., Şen, A. İ., \& Parmaksızoğlu, A. (2011). The effects of out-of school scientific activities on 9th grade students' relating the unit of energy to daily life: Necatibey Faculty of Education Electronic Journal of Science and Mathematics Education 5(2), 178-198.

Ertaş-Kılıç, H., \& Şen, A. (2014). The effect of physics education based on out-of-school learning activities and critical thinking on students' attitudes. Education and Science, 39(176). http://dx.doi.org/10.15390/EB.2014.3635

Eshach, H. (2007). Bridging in-school and out-of-school learning: formal, non-formal, and informal education. Journal of Science Education and Technology, 16, 171-190

Fägerstam, E., \& Blom, J. (2013). Learning biology and mathematics outdoors: effects and attitudes in a Swedish high school context. Journal of Adventure Education ve Outdoor Learning, 13(1), 56-75.

Falk, J. H., \& Dierking, L. D. (2000). Learning from museums: Visitor experiences and the making of meaning. Lanham, MD/Plymouth: Altamira Press.

Field, A. (2009). Discovering statistics using SPSS. London: Sage

Fraenkel J., Wallen N., \& Hyun, H. (2012). How to design and evaluate research in education. New York: McGraw-Hill

Griffin, J., \& Symington, D. (1997). Moving from task-oriented to learning-oriented strategies on school excursions to museums. Science Education, 81(6), 763-779. 
Güler, A. (2011). Impact of a planned museum tour on the primary school students' attitudes. Elementary Education Online, 10(1), 169-179.

Hoy, W. A., \& Spero, B. R. (2005). Changes in teacher efficacy during early years of teaching: Acomparison of four measures. Teaching and Teacher Education, 21, 343-356

Hu, L., \& Bentler, P. M. (1999). Cutoff criteria for fit indexes in covariance structure analysis: conventional criteria versus new alternatives. Structural Equation Modeling, 6(1), 1-55. http://dx.doi.org/10.1080/10705519909540118

Kalaycı, Ş. (2006). SPSS uygulamalı çok değişkenli istatistik teknikleri. Ankara, Asil

McComas, W. F. (2006). Science teaching beyond the classroom: The role and nature of informal learning environments. The Science Teacher, 72(10), 26-30.

MEB. (2019) Milli Eğitim Bakanlığı Okul Dışı Öğrenme Ortamları Kılavuzu. https://acikders.ankara.edu.tr/pluginfile.php/118732/mod resource/content/0/13.hafta\%20\%28 mebkilavuz\%29.pdf sayfasından erişilmiştir.

Meydan, C. H., \& Şeşen, H. (2011). Yapısal eşitlik modellemesi ve AMOS uygulamaları. Ankara: Detay.

Meyers, L. S., Gamst, G., \& Guarino, A. J. (2006). Applied multivariate research: Design and interpretation. London: SAGE Publications.

Nadelson, L. S., \& Jordan, J. R. (2012). Student attitudes toward and recall of outside day: An environmental science field trip. The Journal of Educational Research, 105(3), 220-231.

Pallant, J. (2015). SPSS survival manual: A step by step guide to data analysis using IBM SPSS. Sydney: Allen \& Unwin.

Parvin, J., \& Stephenson, M. (2004). Learning science at industrial sites. M. Braund, \& M. Reiss (Ed.), Learning science outside the classroom içinde (s. 129-137). London/New York: Routledge Falmer

Salmi, H. S. (1993). Science centre education: Motivation and learning in informal education. (Master thesis). University of Helsinki, Finland. http://files.eric.ed.gov/fulltext/ED363613.pdf sayfasindan erişilmiştir.

Schermelleh-Engel, K., \& Moosbrugger, H. (2003). Evaluating the fit of structural equation models: tests of significance and descriptive goodness- of-fit measures. Methods of Psychological Research Online, 8(2), 23-74.

Schumacker, R. E., \& Lomax, R. G. (2004). A beginner's guide to structural equation modeling. London: Psychology Press.

Seçer, İ. (2015). SPSS ve LISREL ile pratik veri analizi. Ankara: Anı Yayıncılık

Senemoğlu, N. (2004). Gelişim öğrenme ve öğretim. (10. Bask1). Ankara: Gazi Kitabevi 
Smith-Sebasto, N. J., \& Smith, T. L. (1997). Environmental education in Illinois and Wisconsin: A tale of two states. Journal of Environmental Education, 28(4), 26-36.

Sturm, H., \& Bogner, F. X. (2010). Learning at workstations in two different environments: a museum and a classroom. Studies in Educational Evaluation, 36, 14-19.

Şen, A. İ. (2019). Okul dışı öğrenme ortamları. Ankara: Pegem Akademi

Şen, A. İ., Ertaş-Kılıç, H., Oktay, Ö., Ekinci, S., \& Kadirhan, Z. (2021). Learning science outside the classroom: development and validation of the out-of-school learning environments perception scale. Journal of Outdoor and Environmental Education 24, 19-36, https://doi.org/10.1007/s42322$\underline{020-00070-7}$

Şencan, H. (2005). Sosyal ve davranışsal ölçümlerde güvenilirlik ve geçerlilik. Ankara: Seçkin Yayıncılık

Şentürk, E., \& Özdemir, Ö. F. (2014). The effect of science centres on students' attitudes towards science. International Journal of Science Education, 4(1), 1-24.

Tabachnick, B. G., \& Fidell, L. S. (2001). Using multivariate statistics. (4th. Ed.) MA: Allyn \& Bacon, Inc.

Tal, T. (2012). Out-of-school: Learning experiences, teaching and students' learning. B. J. Fraser, K. Tobin, \& C. J. McRobbie (Ed.), Second international handbook of science education içinde (s. 1109_ 1122). Dordrecht: Springer Netherlands.

Tezbaşaran, A. (1997). Likert tipi ölçek geliştirme kılavuzu. Ankara: Türk Psikologlar Derneği Yayınları.

Thomas, G. (2010) Facilitator, teacher, or leader? Managing conflicting roles in outdoor education. Journal of Experiential Education, 32(3), 239-254.

Tortop, H., \& Özek, N. (2013). Proje tabanlı öğrenmede anlamlı alan gezisi; güneş enerjisi ve kullanım alanları konusu. Hacettepe Üniversitesi Eğitim Fakültesi Dergisi, 44(44), 300-307.

Van Prooijen, J. W., \& Van der Kloot, W. A. (2001). Confirmatory analysis of exploratively obtained factor structures. Educational and Psychological Measurement, 61(5), 777-792. doi: 10.1177/00131640121971518

Yavuz, M. (2012). Fen eğitiminde hayvanat bahçelerinin kullanımının akademik başarı ve kaygıya etkisi ve öğretmen-öğrenci görüşleri. (Yüksek lisans tezi). https://tez.yok.gov.tr sayfasından erişilmiştir.

\section{Extended Summary}

Out-of-school learning environments include informal and non-formal learning environments, which enable students with different learning opportunities that are non-existent in traditional learning environments (Ertaş, Kılıç, \& Şen, 2014). Non-formal learning environments support individuals' learning process, they are pre-prepared and structured, and they are under the guidance or leadership of the teacher. In non-formal environments, learning is not sequential and generally not assessed; rather, they create the opportunity for knowledge to be constructed and developed. In 
addition to this, informal learning environments emerge spontaneously and randomly, and they are not purposive or planned; in informal learning environments, learning takes place under the leadership of the learner and is not assessed (Eshach, 2007). Out-of-school learning activities enable the use of non-formal and informal learning environments for formal learning (Salmi, 1993). It has been demonstrated that out-of-school learning activities have a positive effect on students. Hence, if teachers carefully design activities and practices, it can considerably assist the goals of the curriculum, too (Andrew, Maggie, \& Sarah, 2010). Contrary to this, unorganized and unplanned activities of the out-of-school learning environments cannot meet the targets. According to Bandura (1986) "what people think, believe, and feel affects how they behave" (p. 25). Self-efficacy beliefs are also seen as an important factor affecting these behaviors. Self-efficacy beliefs are viewed as the base of teachers' motivation levels and personal accomplishments; unless teachers believe in their ability and capacities to accomplish out-of-school learning activities, they will make a little effort or no effort toward out-ofschool learning activities. In this context, the present study aimed to develop a scale to measure teachers' self-efficacy beliefs toward out-of-school learning (OoSL) activities

A total of 332 teachers participated in the study to develop a scale for teachers' self-efficacy beliefs toward out-of-school learning (OoSL) activities. From a different type of school 332 teachers participated in the scale development process. Upon the review of the related literature, the required common procedures followed by different researchers in the process of scale development were identified (Crocker \& Algina, 1986; DeVellis, 2017; Tezbaşaran, 1997). According to these stages, items were written according to Bandura's self-efficacy theory. When establishing the item pool, the related literature was reviewed to examine qualitative studies and measurement tools utilized in studies related to OoSL and self-efficacy. Subsequently, 10 teachers in different grade levels were asked to write a composition reflecting their feelings, opinions, and experiences related to the topic. As a result, based on both the compositions and the related literature, a 40-item item pool was constructed. For the statements in the scale, a 5-point Likert scale was utilized: 1- Strongly Disagree, 2-Disagree, 3-Partially agree, 4-Agree, 5-Strongly agree. To ensure the content validity of the scale, the opinions of six experts were sought: one expert in the field of measurement and assessment, three experts in curriculum and instruction, one mathematics teacher, and one science and technology teacher. To minimize the potential problems in the main implementation, a pilot study was performed with 10 secondary school students. The necessary modifications were made based on the results of the pilot study and expert opinions, the scale consisting of a total of 33 items -17 negative and 16 positive -with negative items scored in the reverse direction, the scores were entered into the computer. EFA, reliability analyses, and item analyses were conducted using the SPSS 22.0 software, while CFA was performed via Lisrel 8.8 . 
As an outcome of the present study, a 29-item scale, consisting of 14 negative and 15 positive items, was developed. The scale explains $61.01 \%$ of the total variance. The results of the EFA revealed that the scale measured a four-factor structure. The four factors were labeled as follows: Factor 1"planning self-efficacy", Factor 2-"implementation and assessment self-efficacy", Factor 3-"self-efficacy to support learning", and Factor 4-"knowledge and experience self-efficacy". The results of the CFA revealed that the fit indices of the three-factor structure of the scale indicated "acceptable fit" and "perfect fit". The results obtained from the EFA and CFA showed that the construct validity of the self-efficacy scale for OoSL activities was ensured. The reliability of the measures obtained from the self-efficacy beliefs scale toward OoSL activities was analyzed with the Cronbach Alpha and combined reliability methods. It was revealed that the measures of reliability coefficients were above .78 for all four factors and the overall scale. It is indicated in the related literature that measures of .70 and above are reliable (Büyüköztürk, 2019; Field, 2009; Fraenkel, Wallen, \& Hyun, 2012). The results of Tukey's Test for Non-Additivity indicated that the scale was additive. Within the scope of the item analysis of the self-efficacy beliefs scale toward OoSL activities, the item-total correlation was analyzed, and the $27 \%$ bottom-top group comparisons were made. The results of the analysis demonstrated that the item-total correlations ranged between .424 and .824 and that the $t$ values regarding the differences between the $27 \%$ bottom-top were significant for all the items in the scale. These findings indicate that all the items in the self-efficacy beliefs scale toward OoSL activities are discriminatory.

In the scale for teachers' self-efficacy beliefs toward OoSL activities, the scores that can be obtained from the dimension of "planning self-efficacy" can range between 11 and 55, "implementation and assessment self-efficacy" can range between 10 and 55, and those that can be obtained from the dimensions of "self-efficacy to support learning" and from knowledge and experience self-efficacy" can range between 4 and 20. A total score can be obtained from the scale ranging between 29 and 145 .

\section{Ek 1. Okul Dışı Öğrenme (ODÖ) Faaliyetlerine Yönelik Öğretmen Öz-Yeterlik İnançları Ölçeği OKUL DIŞI ÖĞRENME (ODÖ) FAALIYYTLERİNE YÖNELİK ÖĞRETMEN ÖZ-YETERLİK INNANÇLARI ÖLÇEĞİ}

Aşağıda "okul dışı öğrenme" faaliyetlerine yönelik öz-yeterlik ifadeleri yer almaktadır. Sizden istenen, ifadelere ne derecede katıldığınızı belirtmenizdir.

Likert tipi cevaplandırma: “Hiç Katılmıyorum, Katılmıyorum, Biraz Katılıyorum, Büyük Ölçüde Katıliyorum, Tamamen Katıliyorum" 


\section{Ölçek Maddeleri}

\begin{tabular}{|c|c|}
\hline 1. & "Kazanımlara göre ODÖ faaliyeti hazırlamakta zorlanırım. \\
\hline 2. & ODÖ faaliyetleri ile ders kazanımlarını günlük hayatla ilişkilendirebilirim. \\
\hline 3. & ODÖ faaliyeti ile öğrenmenin kalıcılığını arttırabilirim. \\
\hline 4. & ODÖ faaliyeti ile öğrencilere üst düzey beceriler kazandırabilirim. \\
\hline 5. & ODÖ faaliyetleri ile öğrencilerde ilgi ve merak uyandırabilirim. \\
\hline 6. & *Alanımla ilgili ODÖ faaliyeti düzenlemekte zorlanırım. \\
\hline 7. & *ODÖ konusunda yeterli bilgiye sahip değilim. \\
\hline 8. & *ODÖ faaliyeti gerçekleştirme konusunda tecrübesizim. \\
\hline 9. & *ODÖ faaliyetine öğrenci katılımın sağlanması için velileri ikna etmekte zorlanırım. \\
\hline 10. & ODÖ faaliyetine yönelik plan ve hazırlıkları yapabilirim. \\
\hline 11. & ODÖ faaliyeti öncesinde ilgili kişilere gerekli bilgilendirmeleri yapabilirim. \\
\hline 12. & ODÖ faaliyetine yönelik gerekli izin ve işlemleri yürütebilirim. \\
\hline 13. & ODÖ faaliyeti öncesi karşıma çıkan engelleri aşabilirim. \\
\hline 14. & Yasal prosedürleri gözeterek ODÖ faaliyeti düzenleyebilirim. \\
\hline 15. & *ODÖ faaliyeti konusunda ilgili kişi ve kurumlarla görüşmeye çekinirim. \\
\hline 16. & ODÖ faaliyeti öncesinde yaşanabilecek güvenlik sorunlarını öngörebilirim. \\
\hline 17. & *ODÖ faaliyeti sırasında grubun kontrolünü sağlamakta zorlanırım. \\
\hline 18. & ODÖ faaliyeti sırasında karşılaşabileceğim olumsuzluklarla baş edebilirim. \\
\hline 19 & *ODÖ faaliyeti sürecinde yaşadığım stresle baş etmekte zorlanırım. \\
\hline 20. & *ODÖ faaliyeti sırasında güvenliği sağlamakta zorluk yaşarım. \\
\hline 21. & *ODÖ faaliyeti sırasında öğrencilerin dikkatini toplamakta zorluk çekerim. \\
\hline 22. & ODÖ faaliyeti sırasında aktif bir rol üstlenebilirim. \\
\hline 23. & ODÖ faaliyeti düzenleyebilirim. \\
\hline 24. & ODÖ faaliyetinin ne olduğunu etkili bir şekilde gerçekleştirecek kadar iyi biliyorum. \\
\hline 25. & *ODÖ faaliyetini etkili bir şekilde gerçekleştiremeyebilirim. \\
\hline 26. & *ODÖ faaliyeti sırasında öğrencilere gerekli açıklamaları yapmakta güçlük yaşayabilirim. \\
\hline 27. & ODÖ faaliyeti sırasında öğrencilerin sorularını rahatlıkla cevaplayabilirim. \\
\hline 28. & *ODÖ faaliyeti konusunda sorumluluk almaktan kaçınırım. \\
\hline 29. & *ODÖ faaliyetlerini değerlendirmekte zorlanırım. \\
\hline
\end{tabular}

*'şaretli maddeler ters kodlanmaktadır.

\section{Araştırmacıların Katkı Oranı Beyanı}

$\mathrm{Bu}$ araştırmada; literatürün taranması, verilerin toplanması, analiz edilmesi ve makalenin yazım aşamalarında yazarlar birlikte çalışmış, çalışmaya eşit oranda katkı sağlamıştır.

\section{Destek ve Teşekkür Beyanı}

Bu çalışmaya desteğini sunan katılımcı öğretmenlere ve uzman olarak görüşlerini beyan eden akademisyenlere teşekkürlerimizi sunarız.

\section{Çatışma Beyanı}

Araştırmacının araştırma ile ilgili diğer kişi ve kurumlarla herhangi bir kişisel ve finansal çıkar çatışması yoktur.

\section{Etik Kurul Beyanı}

Bu araştırma, T.C. Bandırma Onyedi Eylül Üniversitesi Sosyal ve Beşeri Bilimler Etik Kurulunun 18.06.2020 tarih ve 2020-3 sayılı onayı ile yürütülmüştür. 